\title{
The Stage That Does Not Exist: \\ Irkutsk Open Market as a Dramaturgical Metaphor
}

\author{
Dmitriy O. Timoshkin ${ }^{\mathrm{a}, \mathrm{b} *}$ \\ ${ }^{a}$ Irkutsk State University \\ 1 Karl Marx Str., Irkutsk, 664003, Russia \\ ${ }^{b}$ National Research Tomsk State University \\ 34, Lenina, Tomsk, 634050, Russia
}

Received 23.07.2018, received in revised form 26.10.2018, accepted 09.11.2018

The article deals with the representation practice of Irkutsk open clothes market in urban narratives. The concepts of social roles performed in the market space and markers, indicating its boundaries, are analysed in the article. Referred in the narratives nonspatial market borders, which are characterized by the changes in the role model and ideas about the permissible, are considered in the article. The purpose of the article is to show the market from the position of several groups acting in its context. The theoretical framework of the article is E. Goffman's dramaturgical metaphor and W. Benjamin's approach to the description of urban localities. Based on this empirical material the article hypothesizes several ways of urban space representation in dialogues, depending on each person's role. Practice, that all respondents mention despite their group membership, becomes the actual content of locality. In the case of Irkutsk open market this practice is informal earnings.

Keywords: open market, dramaturgical metaphor, urban narrative, informal networks.

The research was supported by the Ministry of Education and Science (the basic part of the State assignment, project No. 28.9753.2017/8.9) and partly (analysis of practices of using urban infrastructure by migrants) by the grant from the Russian Science Foundation No. 18-18-00293.

Research area: sociology.

Citation: Timoshkin, D.O. (2018). The stage that does not exist: Irkutsk open market as a dramaturgical metaphor. J. Sib. Fed. Univ. Humanit. soc. sci., 11(11), 1776-1791. DOI: 10.17516/1997-1370-0339.

The article discusses the role structure of the open market in the center of Irkutsk. The choice of the object was determined by its unique characteristics and functions that it performed in the everyday life of the city. The market was an extremely

(c) Siberian Federal University. All rights reserved

* Corresponding author E-mail address: dmtrtim@gmail.com

This work is licensed under a Creative Commons Attribution-NonCommercial 4.0 International License (CC BY-NC 4.0). 
important place for post-Soviet Irkutsk, replacing the system of state social insurance in a situation of uncertainty for many citizens. It became the site for the "migrant" infrastructure formation. Networks uniting migrants and representatives of the host community, which helped both the migrants and the representatives to integrate into the "post-Soviet" city, arose here.

The market can be viewed as a metaphor for the transition of the "Soviet" city to a new state, suggesting new rules and new opportunities. It was the place where business was learning to survive, the visitors were learning to bargain and interact with newcomers, the pickpockets were learning to steal money from the wholesalers, and the city authorities and security forces were learning to charge rent from all of them. The market generated a huge number of specific practices, some of which became the landmarks of the city center.

In a sense, the market has become a "frontier" between two types of the city. This status of the place was emphasized by the information wars that constantly arose around it: some citizens considered it to be absolutely unacceptable. These were not its aestheticism, abundance of crime and unpredictability that were criticized. Opponents, in turn, pointed to the widest range of goods available to everyone, ranging from food and clothing, to fishing gear and household appliances, as well as the convenience of its location in the city center. The market turned into one of the most "advanced" places in the city: a quick walk, quick deals and an instant change of scenery if necessary. All these factors turned it into one of the key centers of social and informational activity.

Dynamism, developed informality, and a combination of a large number of unique practices that arise in the situations of uncertainty turn the open market into a promising field for transitional states studies. The city locality is going to be analyzed from two positions. One of them is the situation of "flâneur" by W. Benjamin, that articulates its subjective experience and is expressed in the narratives of the experiences of "others" interacting with the object.

Another position is E. Goffman's dramaturgical metaphor. It can be considered as the absolutized phrase by W. Shakespeare: "All the world's a stage, And all the men and women merely players". The interaction of groups is considered as a set of performances, determined by collective ideas about the "acceptable" and "unacceptable" behavior on a particular social stage. E. Goffman considers social stage as a context where the interaction of groups is taking place. As well as the theatre stage, it contains a lot of markers that allow actors to recognize it and select the correct model of behavior. Each 
actor performing on the social stage chooses a model of behavior based on their own ideas about the collective expectations of the audience and other participants on the stage.

The dramaturgical metaphor used as a theoretical framework in the open market study allows presenting locality as a unity of disparate experiences, united by a common, not necessarily spatial, boundary. The role of the observer as the "other one", placed in an atypical context, makes it easier to identify and record practices perceived as a "norm" by those immersed into the daily routine of the market. At the same time, the problem of false interpretations, which, however, can be solved by following the ethnomethodological principle - to abandon them as much as possible, arises. W. Benjamin's approach allows the viewer of the Goffman's drama to become a full-fledged actor, adding his/her own subjective observations to the description of the interaction of "others" on the stage. The flaneur's method, or, putting it simply, the method of street onlooker, boils down to the trivial researcher's experience of the locality and further description of his/her own sensations: danger/safety, convenience and casual events.

The purpose of this article is to show the market from the standpoint of several groups operating in its context, to describe the features of their interaction, as well as to try and determine the market based on the specific features of its "scenery" and the roles performed here. The study was carried out on the basis of 15 interviews taken in the market, as well as the social media and mass media narratives.

\section{Swindler, commoner and merchant}

Based on the narratives it is possible to identify three main groups of people in the open market, whose interaction determines its structure: swindlers, including pickpockets, vagrant children, representatives of state law enforcement structures, traders and visitors. This classification is, of course, quite conditional. People can easily combine multiple roles at the same time. The respondents who work at the market may not consider themselves as traders, defining themselves as, for example, dentists, mining engineers or teachers. There are also more complex models of selfrepresentation. One of the respondents, a former law enforcement officer, defined his role in the following way: "It (the open market) was a typical representative of such chaos. What role did I play there? The role of the CCTV and nothing else. As an eagleeyed person."

Depending on the group the respondent identifies him/herself with, the interaction of groups in his/her narrative is arranged in two formats - confrontation and symbiosis. 
Moreover, within a single story, confrontation may be replaced by alliances, forced or voluntary ones. So, for buyers, the traders played the role of a trickster, being comical, roguish and threatening, but, at the same time, giving a possibility for profit. The traders tried to sell the goods as expensive as possible, while, as one respondent said, they tried to "rip off" the buyer as much as possible by imposing an unnecessary or inappropriate thing. The traders could bring a piece of clothes of an unsuitable size to the next pavilion, stretch it on their knees and bring it back to the customer as a new piece.

In the narratives of market visitors, the traders could become antagonists. For instance, in the situations where they demonstrated excessive perseverance, or tried to "push" poor-quality goods. For vagrant children the traders, on the contrary, became assistant heroes, as they gave (voluntarily or involuntarily) food and clothes, and sometimes a day-to-day job: "We even carried boxes for them. We even worked, carried boxes for them. You come there, load them onto the trolleys and carry. And that's it. (Then) we pointed at a jacket or footwear and they gave it. We often went to them. They knew us. Sometimes it happened that they came there themselves, or caught some of the boys - let's go? Let's go. You spent for about two hours there carrying boxes."

The groups could conflict with each other over the territory possession. One of the respondents, who lived in the basements near the market, said that "Chinese" traders often tried to make them leave the basement: "One night we heard some noise, looked out onto the street (it was winter) and saw a crowd of Chinese. They, for some reason, were stripped to the waist and armed with sticks, and started loudly demand that we leave. We jumped out into the street, there were about 30 of us, the Chinese threw down the sticks and ran away."

Sometimes the traders declared war on the administration or the market owner, when they were engaged in completely unscrupulous extortion or threats. The merchants united into groups and tried to defend their rights: "And then they announced that the market was closing and that there would be free parking lot for the city. $<\ldots>$ We were on strike, demanded to leave the market to us, as there were people who lost their jobs, there were even professors, different people, and they were there, trading. Someone sewed clothes themselves, someone repurchased and brought something. All those who lost their jobs in those years traded there." According to the respondents, such stories could end badly for the traders: their pavilions could be opened at night, and if they kept the goods there, they faced great losses.

In each case, when a kind of alliance arose between the groups of "antagonists" in the context of the market, the structure of the market as a social stage was redefined. 
Opposition was replaced by cooperation; the trader dedicated the "trusted" buyer to the hidden practices related to his/her role performance. A hint at what kind of goods is of poor quality puts the buyer in a privileged position: he/she was separated from the crowd, and he/she, unlike other buyers, will not buy an outright junk. Such contacts preserved even after a lot of sellers moved from Shankhaika to other retail areas. Sometimes people purposefully spent their days trying to find "their" trader in a new place.

The open market constant was pickpockets. The same people "had been working" in the market for many years, some traders knew them by sight, knew their name, and even greeted them sometimes. Judging from the traders and the pickpockets' stories, the police almost never interfered in their activities, as it is impossible to catch a pickpocket in the act. In addition, some pickpockets paid regular bribes to the local police, so after their detention they were released without any problems. This group also determined the stage of the open market, dictating its own rules: "Why do I say they go in a group of two or three? One puts his hand (into the pocket), the second one stands watching. $<\ldots>$ If one of them is arrested, someone reported on them, the second one leaves without attracting attention and tells who sold them in. And that person faces problems. <...> He/she might be cut or something else. There have been a lot of such cases. I mean they were generally afraid. Here, they stand and look while the person was being pickpocketed, and the person who was pickpocketed comes to the traderyou saw it! And the trader says: "I did not see anything." He says nothing out of fear. Q: And what about the police? A: At that time <... everything was solved by money. Hel she could give some money and that's it, the policemen kept silence, whatever he/she does, even if that person is crazy out there, they are absolutely indifferent." The traders and pickpockets sometimes changed roles. Some thieves, who managed to accumulate initial capital, opened their pavilions on the market. It was easy to accumulate such a sum - the weekly income of one pickpocket could be hundreds of thousands of rubles.

The relationships of the traders and the thieves sometimes became symbiotic. The respondents reported on cases when the traders worked together with the pickpockets. Having found a wholesaler who came to buy goods for reselling in another town, the trader tried to consider how much money the latter had after the transaction was made, and then he brought pickpockets to him. According to the respondent traders, there were no cases when they would enter into alliances with buyers against pickpockets, although the buyers themselves mentioned such cases. For example, one of the respondents recalled a case when a girl in ragged clothes returned his stolen bag with 
all the money and documents and immediately disappeared. Another one told how the traders brutally beat the thieves who were caught: " $Q$ : And were there cases when the traders themselves punished the people who had stolen something from them? A: Well, it was when men fought. They beat each other unmercifully. <...> Andrey then had his teeth knocked out, I saw that. And he was in the hospital."

Several "brigades" of thieves worked in the market, and there were not to "snitch" agreements between them and the traders. That is, if the trader saw that his buyer was being pickpocketed, he could not warn him/her, as this could cause the trader great troubles. It was mentioned that pickpockets, especially in case of such conflicts, had razor blades in their mouths, and could cut the face of the person who had "snitched" them. Sometimes these conflicts ended by the hospital, which, however, happened rarely, as it attracted (as opposed to pickpocketing) police attention.

The law enforcement officers can also be attributed to the conditional group of swindlers, since, judging by the narratives, the actions of both were reduced mainly to charging informal rent from the traders and buyers. The law enforcement officers act as operators of both legal and illegal practices on the market, ranging from controlling the circulation of counterfeit goods to drug traffic. They are exposed as antagonists by both the traders and marginalized communities. The visitors mentioned the law enforcement officers either talking about market raids or complaining about the lack of opportunity to get protection in case of mugging or pickpocketing.

From time to time, the police entered into alliances with the traders and marginalized groups. Vagrant children, for instance, stole weapons and badges from the law enforcement officers during the police raids on basements. The police officers could not admit that teenagers took their weapons away, and they had to "wine and dine" the vagrant communes. Sometimes the law enforcement officers made deals with the children, "allowing" them to live in the basement in exchange for the fact that they would supply them with the "information" if necessary. The traders more often recall the police in connection with the raids, during which money and goods were taken from them. The law enforcement officers, however, could also act as assistants when, for example, they warned the market administration about the forthcoming raid, and the administration, in turn, informed the traders. Everyone, who had something to hide, closed their pavilions and left the market.

A similar position is taken by another group, "the market administration", which is not introduced anywhere except for the traders' stories. The role of the administration is similar to the one that is assigned to the law enforcement officers: the collectors 
of constantly increasing formal and informal rent and the source of problems and hardships. One of the respondents, for example, told about the existing tradition of the market administration to collect "the forthcoming year" fees from the traders. This fee is charged, for example, at the time when the trader goes on holiday. If on return he/she does not pay "the forthcoming year" fees again, they do not extend the contract with this person. Another type of charges is collection of huge amounts for the services that clearly do not worth it.

The "administration" could also act as a power resource operator, solving such tasks by the private security guards. Formally, the role of the latter was to protect the visitors and the traders from marginals. In fact, at least in the narratives about the past of the market, the guards robbed the traders themselves and charged the thieves and the buyers for entering the market. The "administration" solved problems related to land ownership rights with their help. Thus, one of the traders told about cases when the guards, on behalf of the "administration", demanded to transfer the land owned by the trader, threatening, otherwise, to "throw the person out" from the market.

Different groups can recreate absolutely different, sometimes contradictory descriptions in their stories. One of the examples is when vagrant children, who live in the surrounding basements, and clerks, who come to have dinner there, tell about the market. The activities of these people will be determined by different rituals and perceptions of the permissible, but, in fact, they will act in parallel "physical" realities. A vagrant child will describe the basements, fights with the police, hunger and going under the counters, the clerk can tell you about the way from the office to an inexpensive tea house and about the degree of meat roasting in an exotic dish. A buyer can tell about the quality of "Chinese" clothing, about unthinkable color combinations and curiosities, about how he/she successfully "tricked" the trader. What becomes a shock to a visitor can be described as a not worthy of attention norm for a trader, a law enforcement officer or a vagrant child. The market connected the routes of such dissimilar groups into a single whole, and this was probably the reason for its unique functionality.

\section{"Non-spatial" boundaries of the open market stage}

In most narratives the respondents call the market in the city center "Shankhaika". This toponym means not so much a specific place, but a type of social relations - in the collected material it is possible to find a lot of different points on the world map, which are named "Shankhaika": "Krasnodar is a contrast in general. There is a district 
named "Shankhaika" or ghetto by the common people"; "Little by little Bol'shaya street (in Divnogorsk) is bought up for warehouses and transshipment terminals, in some time everything will look like "Shankhaika"; "At the farthest end of the Angara "Shankhaika" there is a department where Mongolian goods are traded. <..> The prices are very cheap, and you can bargain with the owner of the stall, he reduces prices."

In fact, despite regular statements about its closure, the market in the city center "Shankhai" have existed for more than 20 years almost intact. The question why something that should not be here is still here, becomes a subject of discussion as well. "Extraneity" of the place for the imaginary "city of the future" is becoming one of the symbolic boundaries denoting it: "It is high time to remove both the central market and "Shankhaika" from the city center! I don't know what you think, but I'm afraid to walk in that area! There are always some bums with cups and cripples rushing there... There are so many beggars, terrible. The guests of our city are unpleasantly surprised when they see such a place in the city center." As a result, the residents of Irkutsk call "Shankhaika" open pop-up markets of other cities and other places that are just inconsistent with the respondents" ideas about the "need" for the place.

The instability of locality becomes a common feature of "Shankhaika" visitors" narratives. This implies both unusual and unattractive scenery and blurring the structure of performances. They mention heaps of garbage and a lot of people, unusual objects and color combinations that are difficult to find in other places, the frequent inclusion of inscriptions in a foreign language among the scenery of this place. The locality is represented as "the place that should not exist": "Now the place near the mountain of Jerusalem is not just a district, but an entire town in the city with its cafes, hospitals, hotels, banks, entertainment establishments, and almost all of them work illegally. <...> And, as the deputy mayor of Irkutsk Dmitry Grishak said, there should be no market here at all." This statement gives rise to attempts, in general agreement with the "non-existence" of the place, to determine the reasons why it still exists. Groups attempting to define unstable locality, associate it with the imagined ideal of "the city as it should be", point to the discrepancy, ultimately making a conclusion about the "non-existence" of the place in the future. The place has never "existed". This is what the media wrote about it in 2004, in 2010, in 2014 and 2018.

One of the characteristics of the market boundaries is its space informality. When approaching it, one can see tiny outlets, where it is possible to buy a SIM card of any 
operator without passport. These are stalls with packed SIM cards and several people standing nearby. Sometimes it is impossible to understand who the trader is. And only when you start demonstrating visible interest in the product, the trader tells the price. As you come closer to the market you can see key-making machines installed on the sidewalk, the stalls of "emergency shoe repair", as well as stalls selling food and fruit. Here you can meet people who come up and offer phones, gold, currency exchange and sometimes even drugs, in whisper.

Informality and abundance of discreet rituals provided reduction in the level of unpredictability for those who interacted with the market on a daily basis. At the same time, for a stranger who did not know the intricacies of the market "intrigues", the level of unpredictability was higher than in other city areas.

The change of performance at the moment when the actor gets inside becomes a marker of the market boundaries. "Changing" scenery and roles mark the moment of transition to the play, the rules of which are not always clear to the respondents who acted as "buyers". They only understand the fact that they fall into the field of unpredictability: the result of their actions here may completely oppose to their expectations. Unexpectedness becomes one of the attributes of the "boundary" space, the usual performance here may not lead to the desired result. Coming to the market, a person, as a rule, changes the role. Moreover, the importance of such a role switching is very high: one of the respondents said that as a student he worked at "Shankhaika" selling clothes. When he came to the market and stood behind the counter, he was no longer recognized by the university lecturers and course mates, who bought clothes from him.

One of the markers denoting the boundary of space is the practice of mimicry. People who play marginal roles in the context of the market have to disguise for the most common role. Thus, going to do the "job", pickpockets tried to behave like buyers: they put on expensive clothes, slowly walked around the market and looked at the goods exactly until the moment when they found the victim: "And you can't even say that this is a pickpocket, here they come, such neatniks. <...> They changed clothes every day. They even did it this way, once they did their job, they immediately changed their clothes, in ten or fifteen minutes, and here they come, wearing something new. Already in other clothes. To avoid suspicion. Sometimes such things happened: there were surveillance cameras in the place where we lived, the police came and watched the footage, so there he goes wearing one set of clothes, and going to another direction wearing different clothes." 
Homeless people who lived around the market also disguised themselves as buyers. Intending to steal things from the trader, several homeless people started looking and trying on the goods, entering into the dialogue with the trader. The trader lost vigilance, and then the children grabbed things from the counter and the whole group ran away. Going to the market, some buyers put on old and dirty clothes on purpose to buy goods from the trader for a minimal price, referring to their financial distress.

The dangers, real or imagined ones, led to the fact that parents forbade children visiting the market alone. The frequent element of childhood memories were teenage gangs, making money here by extortion and robbery. Young people from the outskirts and nearby small towns and villages came to the market to "make money". One of the respondents described "Shankhaika" of the 90s as a fair of innovative "lottery scams". As soon as a new lottery scams appeared somewhere in the world, it was immediately mastered by the local experts in the market.

Swindlers and thieves became the characters of legends connected with the market, turning into Propp's antagonists on the way of the character-buyer to the cherished "magical" cheap sportswear. Stories about how someone's purse was pulled out with special dexterity "on the market", or how the victim suddenly managed to return the stolen goods, became a part of the folklore that arose here. Until now, visiting "Shankhaika" one can see an unusually dense concentration of pawnshops.

A high degree of uncertainty becomes one of the few constants for an observer who comes to the market from the outside. Crossing boundaries meant the emergence of a multitude of internal rules and restrictions that did not act outside the market. Some respondents extend these rules and rituals to all localities with similar characteristics, like Cherkizovsky Market or Krasnoyarsk open market "KrasTETS". For instance, if a buyer tried on a lot of goods, started bargaining, and then tried to leave without buying anything, in the best-case scenario, he/she could have been attacked verbally, in the worst one - beaten or locked in the pavilion. Some of the rituals meant the transition to the "boundary" area of the market, for example, to carry bags with money under clothes on the chest, to dress as poorly as possible (or richer, depending on the purpose).

The ritual that is inseparably linked with "Shankhaika" is bargaining. It was perceived not only as a unique opportunity, but also as an inevitability: there were no price tags on the goods, and the amount told by the seller was obviously unreasonably high. Both actors on the stage understood this. The most important concept for the local traders - handset (the first sale on the market) is connected with bargaining. The 
handset can be attributed to a variety of trading magic. A lot of superstitious beliefs are associated with it, for instance, the dependence of the handset and the loan: " $Q$ : What is the handset? A: It is the first sale in the morning. Let's say the day begins, who sold the first is called the handset. And another thing, when somebody asks to lend some money, they usually answer: "I have not had my handset yet, I cannot lend". It is a kind of superstitious belief. And when the firs item is sold, you can lend."

The unspoken rule of "Shankhaika" is the inadmissibility of returning goods. Attempts by ignorant people to return a defective or unsuitable item could lead to a fight. This fact made visiting the market a kind of a risky undertaking: the element of confrontation was included into the role model "buyer-seller", where the seller's charisma and cunning fought the buyer's desire to save money and his/her ability to find a common language with strangers. No matter how bad the product was and whatever the difference in size, the trader extolled both the product and the customer to the utmost. One of the respondents called it "dancing with a mirror" - while the client is trying on a piece of clothes, the trader whirls around him with a pocket mirror, being profuse in compliments. The buyer had not to fall for the seller's flattery, to assess the quality of the product, and if it turned out to be of decent quality, by no means he/she should give a sign and start bargaining.

There is another superstitious belief. If the first client buys something, the day will be profitable. Knowing this, some buyers came to the market as early as possible and, finding a trader who had not had customers, bargained till the last breath, buying for a tenth of the original price. Sometimes the traders themselves asked the buyer to "take pity" and buy an item at least at its prime cost. When meeting, the traders have a tradition to ask if there is a handset and to wish "the handset" to each other.

The very fact of crossing the conditional boundaries of "Shankhaika" implies the choice of one of the rather rigidly defined roles. At this moment there is no agreement between different actors, and one of the participants in the social situation may be completely unaware of the fact that others have already defined his/her role and expect him/her to play according to the rules the person does not know. Unlike other urban localities, where participants can maintain role neutrality, the very fact of presence here automatically implies role-marking. One glance is enough to determine your role: if a passerby glanced at the goods on the stalls he/she automatically became a buyer, and the traders started attacking.

A lot of sellers are trying to drum up customers (and in some cases, literally drag them away by holding his/her hand). And if you gave in and started looking at the 
goods, the seller will do his/her best not to let you leave empty-handed. If a visitor saw the entire range and chose nothing, the trader carefully asked what item was needed and ran after it to the neighboring stalls. The trader did everything possible to not miss the client. To get rid of an obsessive trader, the respondent said that he/she needed to withdraw money from the ATM. The trader wanted to go with the buyer.

Both buyers and traders use slang to denote each other. For example, in the "KitaiGorod" market, where many merchants moved in 2013 from the "Old Shankhaika", the customers are affectionately called "fools" behind their backs.

The role model of the confrontation between the buyer and the trader is so stable that even when one of the participants on the stage declares that he/she plays an unusual role in the context of the market, this does not change the structure of the stage. For example, in the process of field studies, the interviewer tells the trader that he/she is a university researcher, and the interviewee partially leaves the "trader-buyer" role model. $\mathrm{He} / \mathrm{she}$ no longer needs to deceive the buyer, what implied by the context of the open market, but the deal is made anyway: the researcher receives information and the trader is saved from boredom. If the trader cannot or does not want to give information, he/she sends the researcher to the neighbors. The traders do the same if they want to get rid of an unnecessary or unpleasant customer, or, on the contrary, they want to help their neighbor earn extra money, if they do not have the required product, but the neighbor does.

Sometimes declaring the performance of an atypical role broke the role model entirely. In the same situation with the researcher, when the traders realized that the person was not a buyer, they gathered around the interviewer and started answering the questions all together, and each one was subjected to collective censorship. One of the key laws of the open market - the solidarity of traders united against buyers, was broken. These traders' talks during the interview gave much more information that was simply impossible to get from face-to-face conversation, as they let the interviewer get into their circle, into the hidden area of performance, teasing and accusing each other of lying. Partially, such dialogues reveal what is happening inside the hidden area, usually accessible to the traders only. As a result of one of these collective interviews, it became clear that one of the traders used to make his living at the same market pickpocketing, and how to act to convince a visitor to buy a thing that does not suit $\mathrm{him} / \mathrm{her}$, etc.

In the descriptions the market was highly dependent on the role played by the respondent. "Shankhaika", constructed in childhood memories, can be very different from the one that is created "here and now". A lot of people traveled to the market 
with their families and spent the whole day there, using it as a public weekend space. In this case the market was presented more as a fair than a dangerous borderzone. From childhood memories it is emphasized that the market was the most lively and interesting place in the city and going there was perceived as a holiday.

At the same time, from the perspective of their current role, the respondents associate the market with poverty and danger, emphasizing that parents could not afford buying clothes in other places. The risks associated with the market change in the memories about it the over the years, although the pair "marketunpredictability" remains. If in the memories of a decade-old market, the respondents mentioned the risks of the possibility of becoming a victim of pickpockets, racketeers or con men, today they call the risks of facing rudeness or buying a low-quality item.

The respondent may describe several spaces of different functional and subjective perception. The respondent can also draw boundaries between the "past" and the "future" of the market within one narrative, like between the market and the rest of the city "here and now". Fifteen years ago, "Shankhaika" was a lot of pavilions and cargo containers. The containers were put in several rows, in the lower ones there could be shops, casinos, cafes and toilets, and the traders lived in the upper ones. Currently, "here and now", the market moved into a large shopping center, some stalls were covered with roofs, and the place was asphalted. Huge pools of dirt and thin planks, that became an inherent part of the memories of the "Shankhaikas" in Irkutsk, Krasnoyarsk and Novosibirsk, have sunk into oblivion. The abnormal, in the context of the rest of the city, number of buyers has also disappeared: the traders complain that there are less and less customers every year.

\section{Conclusion}

The question that has to be answered is whether it is possible to talk about some kind of integral model of urban locality, in which its various interpretations would harmoniously combine, when different groups of the respondents construct a completely different experience of interaction with it? To answer this question, it is necessary to understand what, nevertheless, binds the groups that periodically operate within the same city locality, even if they perceive it completely differently? Is it appropriate to say that the unity of locality in the particular group or the mass media's interpretation breaks down as soon as we are confronted with its representation introduced by another group? In this context, the moments of intersection of seemingly diametrically 
opposite routes, or descriptions of the same practices by different social groups seem to be especially important in narratives.

A unique set of rituals and social practices, while retaining some kind of common and rather conditional framework, for instance, "guerrilla" tactics for mastering the city, corresponds to each of these parallel realities. For example, after the ban on trading for foreigners in markets, a curious ritual, which the local traders called the "ranway", appeared. Every morning, those wishing to get a day-work by the counter lined up in front of a huge shopping center. They were chosen as frontmen by the Chinese traders. The meaning of the ritual was actually to lease their own citizenship.

Special premises in the back of the trade pavilions, hidden from the prying eyes by the heaps of clothes, where, in case of the immigration service visit, those who did not have legal status in Russia hid, became a peculiarity of the modern "Shankhaika". There was no need in them in the old markets, where it was always possible to get a loyal attitude of the law enforcement officers for a small bribe.

The perceptions of the market boundaries in different periods vary as well. Previously, the visitors determined it by the abundance of people, rubbish and the sense of danger, as well as by the huge fence surrounding it. The new market does not have such a clear boundary, now the visitors recognize it by the abundance of foreign speech, the loud shouts of the traders and the smells of food. The market is no longer associated with danger.

It seems that "Shankhaika" is a place that is not clearly fixed in space. It is rather a combination of social practices. That is why everything, starting from time and finishing smells, images and sounds is identified as its boundaries. The guerrilla "tactics" of mastering the city, the city as a space and the city as a social state of constant transition will be common. There is deception within "Shankhaika", but this deception is without negative connotations, the deception as the sabotage of wellestablished, but ineffective norms of social interaction.

The infrastructure and the role structure of the market contributed to the fact that the city center in the narratives was perceived and is perceived as a dangerous and unattractive place, which, nevertheless, has to be visited almost every day. In addition to the concentration of cheap goods and food court, there is also a transport hub connecting bedroom communities, the surrounding villages and small towns. Therefore, everyone who came to the city center, appeared to be on the spontaneous market, and, therefore, found him/herself in a situation of unpredictability. It seems that this is what causes the dissonance between the center as it is, and the center as it "should be" in the respondents' narratives. 
But these particular qualities of the market were valued by some visitors and especially by the traders and marginal groups. The market provided an opportunity for everyone who participated in its everyday life to significantly simplify their lives due to the infrastructure formed here, largely based on informal "weak ties". In the context of the "transitional" period and the situation of social chaos, this particular function was the most important. It is a contradiction, but described as an unpredictable and dangerous place, the market, nevertheless, made it possible to reduce unpredictability, for example, due to the massive supply of counterfeit goods or "informal" jobs.

The market provides an opportunity for everyone to take a shortcut, to reduce efforts and to get a permanent source of income or an endless supply of cheap goods simpler and easier than it can be done in other places. "Shankhaika" of the "90s" fed everyone: councilmen, the police, beggars, migrants and usual workmen, gave an opportunity to the pensioners, who sold sunflower seeds here or delivered hot tea to the traders in winter, to survive. Some quite respectable and nowadays honored representatives of the urban elite started their careers and multimillion-dollar fortunes with "a lottery scam."

It seems that the possibility to use unacceptable, in the context of other spaces, practices to bypass the existing state of affairs, is the only thing that unites hipsters who drink Chinese vodka from plastic bags in the underground chufanka (Chinese restaurant), the police, migrants, pensioners and vagrant children. The peculiarities of the role structure of the place and changing scenery led to a strange shift in the respondents' perception of the city center. Being one of the most important places for the survival of a lot of points of sale, it is described as an excluded place, which should not exist at all. Appreciating the city center for the opportunity to use the power of weak ties, people, nevertheless, deny this value.

\section{References}

Benjamin, W. (2000). Ozareniia [Illuminations]. M., Martis, 376 p.

De Certeau, M. (2013). Izobretenie povsednevnosti [The Practice of Everyday Life]. SPb., Izdatel'stvo Evropeiskogo universiteta v Sankt-Peterburge, 330 p.

Dyatlov, V.I. (2014). Kitaiskii rynok “Shankhai” v Irkutske: rol' v zhizni gorodskogo soobschestva ["Chinese" Market "Shanghai" in Irkutsk: Its Role in the Urban Community Life]. In Izvestiya Irkutskogo Gosudarstvennogo Universiteta [The Bulletin of Irkutsk State University], 10, 103-119.

Goffman, E. (2000). Predstavleniia sebia drugim v povsednevnoi zhizni [The Presentation of Self in Everyday Life]. M., Kanon-Press-Ts, 302 p. 
Grigorichev, K.V., Dyatlov, V.I. (2017). Kitaiskie rynki Rossii: rol’ v postsotsialisticheskoi transformatsii (sluchai Irkutska) [“Chinese Markets" of Russia: The Role in the Post-Sustainable Transformation (A Case Study of Irkutsk)]. In Vestnik Tomskogo gosudarstvennogo universiteta [Tomsk State University Journal], 419, 121-132.

Propp, V. (2001). Morfologiia volshebnoi skazki [Morphology of the Folktale]. M., Labirint, 192 p.

\title{
Сцена, которой нет: открытый рынок в Иркутске с позиции драматургической метафоры
}

\author{
Д.О. Тимошкин ${ }^{\mathrm{a}, \boldsymbol{\sigma}}$ \\ ${ }^{a}$ Иркутский государственный университет \\ Россия, 664003, Иркутск, ул. Карла Маркса, 1 \\ ${ }^{6}$ Национальный исследовательский \\ Томский государственный университет \\ Россия, 634050, Томск, пр. Ленина, 34
}

В статье рассматриваются практики репрезентации открытого вещеевого рынка в Иркутске в городских нарративах. Анализируются представления о соииальных ролях, исполняемых в пространстве рынка, маркеры, отмечающие его границы. Рассматриваются упоминаемые в нарративах непространственные границы рынка, характеризуюшиеся изменениями ролевой модели и представлений о допустимом. Цель статьи - показать рынок с позиций нескольких действующих в его контексте групп. Теоретической рамкой работы стали драматургическая метафора И. Гофмана и подход к описанию городских локальностей В. Беньямина. На основании упоминаемого эмпирического материала выдвигается гипотеза о множественности репрезентаичионых моделей городской локальности в зависимости от исполняемой конкретным актором роли, где фактическим содержанием локальности становится практика, универсальная для нарративов всех включенных в нее групп. В случае открытого рынка в Иркутске такой практикой становится неформальный заработок.

Ключевые слова: открытый рынок, драматургическая метафора, городской нарратив, неформальнье сети.

Исследование проводилось при поддержке Министерства науки и высшего образования (базовая часть государственного задания, проект № 28.9753.2017/8.9) и частично (анализ практик использования городской инфраструктуры мигрантами) при поддержке Российского научного фонда (грант № 18-18-00293).

Научная специальность: 22.00.00 - сочиология. 